\title{
Preface: Social Science Tests of the 'Butterfly Effect'
}

\section{Ernest Aryeetey and Natalia Dinello}

More than ever before, we live today in an interdependent world. Peter Peterson (2003), the chairman of the U.S.-based Council on Foreign Relations, acknowledged that even a military, economic and geopolitical superpower depends on the rest of the world. In his 2001 Nobel lecture, United Nations Secretary-General Kofi Annan suggested that the world of human activity has its own 'Butterfly Effect'. Nature, he remarked, 'is so small and interdependent that a butterfly flapping its wings in the Amazon rainforest can generate a violent storm on the other side of the earth'. As noted by Paul Streeten (2001), the founder of the multidisciplinary international journal World Development, 'Interdependence exists when one country by unilateral action can inflict harm on (or provide benefits to) other countries. Competitive protectionism, devaluation, deflation or pollution of the air and sea beyond national boundaries are instances'.

The growing global interdependence is reflected not only by the huge expansion in world trade over the last two decades, but also by the massive expansion of capital flows, the easier access to foreign technologies, the growing use of foreign resources for development through international assistance and the changing scope and growth of migration. These expansions have created major opportunities for countries to use resources which were previously not available to them for their own development. Thus it has been possible for the U.S. government to rely on the savings of other economies to finance its huge budget deficits at little cost. But the opportunities have been accompanied by new risks which countries must address. Many economists have wondered whether growing external trade poses any threat to the rural environment, particularly in poor countries, as natural resources are tapped to support growing world demand. There is evidence that stronger economies have been better able to deal with the risks than more fragile ones.

While the external trade opportunities arising from global interdependence are huge, the extent to which these reach all parts of national economies has 
been the subject of debate. Killick (2002) discusses the potential benefits with a look at the static efficiency benefits arising from the classical 'gains from trade' arguments. These are based on the advantages of economies of scale and specialization and competition following international exposure. While the potential benefits may be large at the national level, they diminish as they move to the communities where the poor live. There are far too many structural constraints making it difficult for the poor to take advantage of whatever opportunities may be available to the national economy. A major constraint is, of course, the infrastructure difficulties associated with all poor economies.

In the area of technology transfer, both risks and opportunities accompany the introduction of foreign technologies into poor communities. In general terms, foreign technologies are expected to facilitate production and consumption in ways which were previously inconceivable. And this has been achieved in many places. Farm productivity is expected to rise enormously as a result of major improvements in the resilience of various seed varieties and their capacity to multiply, even under marginal conditions. In terms of consumption, poor rural households are expected to increase their consumption as a result of the newfound ability to grow food over longer cycles and store it using improved methods. But there has always been risk associated with the introduction of new seed varieties. For example, old crop varieties may be destroyed as new technology is not adapted to produce food items with the same attributes as the older varieties in terms of taste and appearance. The possible 'wiping out' of traditional foods as a result of new technologies is well known in many developing countries.

Increased flows of foreign private capital can be easily associated with rapid growth in a number of countries, particularly in Southeast Asia. But it is difficult to find similar cases in other parts of the developing world, and this discontinuity leads to a debate about the conditions under which private capital may boost growth and development. In the same vein, the debate about whether aid does actually lead to economic transformation continues with no end in sight. In more recent times, however, the biggest challenge, as suggested in the globalization literature, has come from the responses to international migration. Increasingly the benefits from migration to both developed economies and the less developed ones are being recognized in terms of the productivity gains acquired from new skilled labor where there was a deficit, and the new remittance flows which facilitate income enhancement in poor countries. In Ghana, for example, the regions which experienced the largest reductions in poverty between 1992 and 1998 were those with the greatest increases in remittances as a share of household receipts. But the benefits and costs of international migration are extremely difficult to measure in a way that is free from passion, particularly as the distinction between "brain 
drain' and 'brain gain' has acquired wide circulation. In any case, it is difficult to justify the movement of highly skilled health professionals from poor to richer countries by any sound economic arguments when health institutions in developing countries can no longer function as a result of this migration.

In light of these contentious issues, it is no wonder that one of the most critical questions today is whether global interdependence - in its current shape and form - is beneficial or harmful for development. Consequently, one of the most vexing dilemmas facing developing countries is whether to embrace or reject globalization. Although much ink has been spilled by academics debating these issues, their resolution is a matter of practice. And it largely depends on specifics - specific means of integrating into the global economy, specific contexts of exercising openness, specific areas of engaging at the international level and specific mechanisms of adjusting to the challenges of globalization. Some developing countries have chosen to distance themselves from key players in the global arena, but most have ventured to test the benefits and disadvantages of global interdependence. Introducing perspectives on a variety of subjects related to trade, foreign aid, migration and development, this volume seeks to translate a general theme about accepting globalization and gaining from deeper integration of various economies and societies into practical questions about the effect of particular trade policies and agreements on poverty, consequences of government actions to reduce migration and the rationale and implications of foreign aid.

This book is organized in three parts: trade, aid and migration. Based on diverse narratives of multiple countries' experiences in the context of globalization, the study highlights both motivations and results of participation in the process of global integration. These narratives reflect multiple tests of global interdependence - the social science incarnation of the Butterfly Effect - which may ultimately suggest how to limit globalization's negative aspects and how to ensure that it is a constructive phenomenon. Addressing a broad range of questions, the book chapters nevertheless overlap in highlighting three major themes: first, the interrelationship among trade, aid and migration as engines of development; second, the importance of conditional acceptance of globalization, that connotes an adjustment to the new global reality depending on specific contexts; and third, the need for effective means of building on global interdependence to maximize its benefits and minimize its costs.

The chapters in this volume were presented at the Sixth Annual Global Development Conference, that took place in Dakar, Senegal, in January 2005. Held under the theme Developing and Developed Worlds: Mutual Impact, the conference was organized by the Global Development Network (GDN), an organization with the dual mission of building research capacity in social science and bridging research and policy. Most of the authors of the book 
chapters represent GDN's network partners in the developing and developed worlds; some of them are the finalists from the annual Global Development Research Medals competition. (Only scholars from developing and transition economies are eligible to participate in this competition.) This book follows another GDN-sponsored publication, Globalization and Equity: Perspectives from the Developing World (Dinello and Squire 2005), which included a set of papers delivered at the Fourth Annual Global Development Conference, held in Cairo, Egypt, in January 2003. The 2005 book highlighted the countries' disparate experiences in globalization and equity but nevertheless maintained that there is a fledgling consensus on the benefits of the developing world's entry into a global universe and the necessity for prudent adjustment to the perils of this endeavor.

\section{INTERRELATIONSHIP AMONG TRADE, AID AND MIGRATION: IMPLICATIONS FOR DEVELOPMENT}

Trade, aid and migration are the important indicators of mutual impact between developing and developed countries. Their strong interrelationship provides a rationale for assembling research findings on trade, aid and migration in one book. It also implies that the tests of the Butterfly Effect should be comprehensive and multifaceted in order to capture the full costs and benefits of global interdependence.

The theme of interconnectedness among various vehicles of development has acquired prominence in the recent literature on globalization (see, for example, Faini and Venturini 1993). As argued by George Cho (1995), there exists a complex interrelationship among trade, aid and development. As developing countries become more and more aware of the limitations and insufficiency of aid alone as a factor of economic growth, they increasingly seek both international trade and aid alone. Not denying the role of aid as a means of promoting development, William Cline (2004) claims that free international trade promises greater benefits to developing countries than aid. According to his estimates, while assistance from rich to poor countries amounts to about $\$ 50$ billion per year, total long-term income gains to developing countries from global free trade could reach $\$ 200$ billion annually. Migration is also considered as an aspect of global integration which evolves together with international trade and capital markets (Kapur and McHale 2005). Some periods are marked by greater mobility of goods and capital, while others may be characterized by more intensive migration (Hatton and Williamson 2003, 1-2). 
This book begins with an essentially optimistic message articulated by Richard Cooper. In his overview chapter Cooper writes: 'Relative to expectations at the dawn of global development policy, the world economy performed outstandingly well during the second half of the 20th century' (1). The evidence he cites ranges from historically unprecedented worldwide growth in average per capita income to declines in poverty and infant mortality, as well as improvement in diets, rising human longevity and the containment or even disappearance of many diseases. Consistent with the notion of interrelationship between trade and foreign aid to developing countries, Cooper attributes successes in extending general welfare to both factors. According to him, world exports grew more rapidly than output in the last 50 years, often leading the way and supporting the conventional wisdom that openness - that is, some form of serious engagement with the world economy - is a significant contributor to growth (5). At the same time, national economies became interdependent in terms of capital. The movement of aid funds and private capital confirmed one of the advantages of engagement with the world economy - the possibility of gaining investment funds not only from domestic savings but also from savings elsewhere in the world (11).

Several articles in this collection continue this theme. The chapter on trade capacity building in Sub-Saharan Africa by Chantal Dupasquier and Patrick Osakwe demonstrates a logical link between trade and aid, showing how aid can help create necessary prerequisites for fair and effective international trade. The authors refer to the high implementation costs of the African countries' acceptance of the Uruguay Round (1986-94) multilateral trade agreements as evidence of these countries' lack of capacity to negotiate effectively on trade issues, to exercise the rights of World Trade Organization membership without jeopardizing important development goals, to formulate effective trade policies, to exploit trading opportunities and to fulfill commitments to the multilateral trading system (78). The authors do not 'doubt that trade, if well managed, could play a very important role in the economic development of African countries. It provides easy access to foreign exchange, new technology and more consumer choice. It also increases efficiency in the use of resources through increased competition and allows the exploitation of economies of scale associated with enlarged market size' (102). However, the poorest countries are unable to take advantage of international trade without building sufficient trade capacity. ${ }^{1}$ Trade-related technical assistance offered by rich countries under the recent Doha Development Agenda (DDA) (since 2001) is one element in a capacitybuilding program which, according to the authors, should be closely integrated into broader means of creating an enabling environment for development.

Working from the perspective of migration and development, another contributor to the book, Dhananjayan Sriskandarajah (see Chapter 6), contends 
that international migration can add to increased trade flows between sending and receiving countries and stimulates investment in domestic education and individual human capital investments. Sriskandarajah is not alone in emphasizing the link among migration, trade and capital: he follows in the steps of Robert Lucas $(2005,3)$ who similarly argued that migrants could promote both trade and investment in their country of origin. Lucas substantiated his thesis by referring to the migrants' better knowledge about trading and investment opportunities and by their ability to enforce contracts through a network of contacts at home, a strategy particularly important in countries with no legal framework for conducting business (117). Furthermore, Adama Konsiega (see Chapter 8) further applies the conventional wisdom about interconnectedness among various factors of development to skilled migration. In the era of globalization,' Konsiega writes, 'Highly talented workers are essentially becoming more globally mobile as goods, services and capital have become more globally mobile over time' (212), thus reinforcing the notion of intellectual circulation as inseparable from trade and capital flows.

This interrelationship among trade, aid (as part of capital flows) and migration also suggests the interconnectedness of economic and political perspectives, a view projected by several contributors to this book. Writing primarily about economic parameters of world development during the last 50 years, Cooper nevertheless goes beyond economics, arguing that civil and political liberties (which also have a significant influence over migration) also spread during this period (13). In Chapter 4 Jean-Claude Berthélemy explores commercial interests as a motive for aid and as a counterpoint to donors' geopolitical interests which also affect decisions about assistance to developing countries. As another example of addressing both economic and political viewpoints, Satish Chand analyzes a remarkable turn in Australian aid policy - from serving primarily commercial interests to expressing political security-related concerns (see Chapter 5).

The existence of an interrelationship among international trade, aid and migration - as documented in this book - may have implications for development in terms of gradually becoming aware of and gaining from global interdependence. A state's entry into a larger world may begin within a single dimension of global integration, which would allow testing of the costs and benefits of being incorporated in the global economy. However, the first access to international resources and opportunities may launch a series of initiatives resulting in a more profound integration. This gradualism can get further impetus if an economic rationale for the integrating strategy is reinforced by political reasons and vice versa. 


\section{EMBRACING GLOBALIZATION: ACCEPTANCE AND ADJUSTMENT}

As a case in favor of embracing globalization, Isidro Soloaga writes in Chapter 1 about the likely impact of trade reforms and implementation of the DDA ${ }^{2}$ on various types of Cambodian households, including the poor. Based on simulations using household expenditures, he comes to the conclusion that although changes in prices expected as a result of the DDA's implementation will have on average an almost nil effect on poverty, the change of the tariff structure to a 7 per cent flat rate would produce an average positive impact on households' income of about 3.7 per cent, almost all of it coming from a reduced tariff on foodstuffs (34). Also, noticeable improvements in the livelihoods of poor Cambodians are expected as a result of employees switching to the industrial sector from both agriculture and services as well as from advances in two key elements of rice production technology. These findings are broadly consistent with conclusions of other studies on possible implications of the DDA. For example, Thomas Hertel and Alan Winters (2005) found, using a global modeling framework, that world poverty will likely reduce under the core DDA scenario, that this reduction will be more pronounced in the longer run, and that complementary domestic reforms are needed to take advantage of the new market opportunities.

As another case in favor of trade liberalization, that is part and parcel of global integration, Carlos Casacuberta, Gabriela Fachola and Néstor Gandelman examine how exposing the Uruguayan manufacturing sector to international trade flows affected employment, capital and productivity (see Chapter 2). Uruguayan market-oriented reforms, launched in the 1970s along with tax structure modernization, trade liberalization and full convertibility of the capital account, form the background of their study. Based on their analysis of data from the Uruguayan Manufacturing Survey for the period 1982-95, Casacuberta, Fachola and Gandelman show that trade liberalization had a strong positive impact on productivity levels: the capital-to-labor ratio must have increased, produced by a switch towards more capital-intensive technologies; the reallocation of factors of production and the adoption of new production technologies generated an important increase in total factor productivity (72-73).

Notably, this rise in productivity happened in Uruguay under very specific conditions. First, unions still maintained significant power in Uruguay, and reforms were often negotiated with them directly. Second, most industries displayed high concentration levels, which gave firms considerable market power, particularly in setting prices (53). According to the authors, highly unionized sectors experienced larger employment creation rates and lower 
employment destruction rates while maintaining their higher productivity over less unionized sectors. At the same time, more concentrated sectors have experienced lower capital destruction levels than less concentrated sectors, which means that the market power derived from concentration was translated into higher capital net creation rates (68).

In both the Uruguayan and Cambodian case studies in this book, the tests of global interdependence yielded (or are expected to yield) positive results which are consistent with other evidence on the benefits of globalization (Srinivasan and Bhagwati 1999; World Bank 2002; Dollar and Kraay 2001, 2002a, 2000b, 2004; Bhagwati 2004). Nevertheless, broad generalizations from these cases are somewhat risky because the advantages of global integration are registered in very specific contexts, accounting for specific adjustments to the challenges of globalization. For example, in Uruguay high levels of industry unionization and concentration may have mitigated any negative effects of trade liberalization for local workers.

Chapter 3 by Dupasquier and Osakwe also highlights the dangers of perceiving international trade as an unconditionally 'good thing'. As confirmed by authoritative observers of the international trade negotiations (Stiglitz and Charlton 2004, 9), the African countries' trade commitments have diverted resources from important development projects, with dire consequences for poverty reduction. However, Dupasquier and Osakwe suggest that performing the same test of global interdependence under conditions of Africa's increased trade capacity - as a result of the set of adjustments - could produce very different results. This cautious, differentiating approach is welcome, considering the results of some influential studies which have shown that there is no simple generalizable conclusion about the impact of trade liberalization on poverty, although the benefits appear to increase over the long run (Winters et al. 2004).

Similarly, Konsiega's message in Chapter 8 is that broad generalizations are not always helpful: much depends on the context. Based on data on skilled migration from seven countries of the Western African Union, he provides evidence of the benefits of migration between capital-rich and capital-poor countries as a powerful factor of growth and income convergence, yet this finding does not stand when migration occurs between developing countries of the Union. Following Anthony Venables (1999), Konsiega concludes, 'An African country should prefer a "North-South" type of integration agreements' (222) in order to extract gains from its participation in the world economy. Furthermore, extending this theme to migration in general, Sriskandarajah stresses, 'Whether the impacts of migration are positive or negative depend[s] very much on the context and how the situation is managed' (180). Believing that not one set of policies is universally applicable, he proposes a matrix of 
policies which might be appropriate for particular contexts (see Chapter 6).

The only chapter in this collection that highlights unconditional acceptance of globalization is that by James Chin in Chapter 7, who presents the views of prospective illegal migrants from China. Consistent with the book's message, his study nevertheless shows the excruciating consequences of this unconditional acceptance. Chin's interviews reveal that the migrants see the world outside China, the West in particular, as an epitome of upward mobility, quick enrichment and personal satisfaction. Their dreams for a better life in the global economy include dazzling images of 'a decent life with [their] own villas and cars,' high income, less competition for jobs and other opportunities, hefty remittances and luxurious houses built at home with money earned abroad (199). Although these dreams are inspired by the success stories of some of their compatriots, they neglect the high costs of illegal migration: enormous monetary payments to 'human cargo' smugglers (up to $\$ 55,000$, according to Chin); complex, potentially fatal journeys to the land of their dreams and the bleak reality of toiling overseas. Blinded by their desires and fantasies, the prospective migrants even idealize so-called snakeheads (organizers or brokers of illegal migration), calling them 'good guys' (192-93) or even 'ministers of nongovernmental labors' and 'directors of nongovernmental bank' (202). This sentiment reflects an inherent aspiration for a world without borders and an infatuation with opportunities associated with globalization. Testing these opportunities with one's own lives constitutes a contemporary drama of migration.

The underlying message, as it is reiterated by several contributions to this volume, is therefore two-fold. Foremost, as manifestations of the Butterfly Effect in international human activity become more and more tangible, practical experience with global interdependence highlights both the glory and anguish of globalization. Therefore, to achieve a smooth and relatively painless integration in the global economy, policymakers should consider specific conditions of entering the larger world and contemplate necessary adjustments.

\section{BUILDING ON GLOBAL INTERDEPENDENCE}

Global interdependence obliges both developed and developing countries to seek a mutual accommodation. Aid offered by rich countries to poor ones is not an expression of benevolence; it is imperative for all parties involved in global integration, to build on interdependence. The articles by Berthélemy and Chand explore motivations behind foreign assistance. Berthélemy provides 
empirical evidence that rich countries' development assistance results from a combination of self-interest and altruism; Chand documents the specific case of Australian assistance to its island neighbors, highlighting the recent shift in emphasis to security as the rationale for aid and interventions.

The official purpose of aid is usually to help lift developing countries out of poverty and stimulate their development, while not substituting local capital investment. However, developing countries' dependence on aid has become a notorious unintended consequence in past decades (van de Walle 2005, Lancaster and Wangwe 2000; Sobhan 1982). Trying to understand the origin of this dependence, Berthélemy highlights the previous research findings on vested interests in maintaining the aid system in recipient countries (Svensson 2000). His contribution, however, consists of providing evidence of the influence of such vested interests on aid-allocation decisions by donor countries. Based on the estimate of an aid-allocation equation, using a yearly panel of bilateral aid commitments granted by 22 bilateral donors - members of the Organization for Economic Cooperation and Development - to 137 developing countries over the 1980 s and 1990 s, Berthélemy demonstrates that trade-related business interests in the donor countries heavily influence their aid policies.

Complementing the findings on the key role of geopolitical interests in donors' aid decisions, Berthélemy confirms that foreign aid is directly beneficial to donors and their close business partners from the developing world. At the same time, the neediest aid recipients are likely to lose whenever aid is granted for reasons other than poverty alleviation. Having uncovered the motives behind aid allocation, Berthélemy proposes a new architecture for international aid, that takes account of the existing global realities and difficulties in changing them. Specifically, he suggests sharing responsibilities between the bilateral and multilateral donors: the bilateral donors would take care of the most promising economic partners, while the multilaterals would concentrate their assistance on the neediest countries. The rationale behind this proposal would be to find incentives for non-altruistic bilateral donors to increase their aid budgets (122). Moreover, this aid architecture should satisfy various players in the global political and economic system and enable them to reap benefits from their interdependence.

Berthélemy's proposal also makes sense in light of the fact that the bilateral donors have been increasingly advised to consider aid effectiveness as a prerequisite of assistance (Hansen and Tarp 2000; Tarp and Hjertholm 2000). For example, Steven Radelet insists that donors be much more goal- and resultsoriented in their aid programs and allocate aid to poorer countries with strong and moderate governance (Radelet 2004). The message of Nicolas van de Walle's (2005) recent book - namely, that aid combined with 'bad governance' 
hurts poor countries in general and the poorest people in those countries in particular - implies that only well-governed countries should qualify for aid, while they need it least.

In this collection of articles Cooper refers to the 'apparent ineffectiveness of aid' (the lack of its association with higher economic growth) unless it is given to 'well-managed countries' (12). Dupasquier and Osakwe observe that assistance for building trade capacity is primarily channeled toward those countries of Sub-Saharan Africa which 'tend to have more effective government, better regulatory framework and more exports' (93). Chand also notes the concerns about the impact and cost-effectiveness of Australian aid and pressures to improve aid effectiveness. However, if aid is provided only to well-managed countries, the poorly governed countries - those that particularly need a relief from a 'poverty trap' to launch the engine of growth (Sachs et al. 2004) - will be excluded, with disastrous consequences for them and the world at large. Berthélemy's proposal that the multilaterals concentrate their efforts on assisting the neediest recipients, instead of targeting the good performers, could therefore correct the bias of bilateral aid (123) and thus help build on global interdependence.

The chapter by Chand supplies some illustrations for Berthélemy's theoretical arguments and their empirical testing. At the same time, it provides an interesting twist on the theme of global interdependence, demonstrating how Australia's aid for development reflects current anxieties about global and regional security. It also reminds that globalization refers not only to economic interdependence but also to political interdependence and mutual security. The latter concern is now located at the center of political thinking in many countries.

Chand's chapter is also intriguing because it reveals a curious reversal of aid policy goals - from the primary goal of 'poverty reduction through sustainable development' which has been officially pursued by Australia since 1997, to the earlier 1984 view that aid policy should be driven by multiple mandates, including humanitarian, strategic and commercial goals (14). Furthermore, it analyzes the latest shift of Australian aid policy toward 'interventionism,' that entails a greater direct involvement on the part of the Australian security forces and other public servants in the neighboring region. This shift represents a rather controversial 'experiment' - reflecting the tensions between the 'altruistic' aid policy and 'self-interest' in aid addressed by Berthélemy's chapter - that may have lessons for the broader donor and recipient communities (122). Similar to Berthélemy, Chand does not lament non-altruistic motives but rather seeks an international aid architecture which would accommodate these motives and rely on compensatory multilateral aid to ensure dividends from global interdependence. 
Writing on the issue of migration, Sriskandarajah also emphasizes the significance of a proactive, although realistic, policy. Considering that the very poor countries stand to lose the most and gain the least from migration (due to brain strain, low return migration potential, poor environment for the productive use of remittances etc.), achieving global poverty reduction requires coordinated efforts on the part of policymakers worldwide (180). Sriskandarajah's proposals include creating an environment for more effective dialogue between those arms of governments which do not traditionally work together - for example, departments responsible for home or immigration affairs and those responsible for international development. Sriskandarajah also emphasizes the need for a 'robust supranational framework' for managing migration. Admitting that this framework cannot be built overnight, he advocates more productive partnerships between developed and developing countries and action on shared development objectives as a relatively easy step forward. ${ }^{3}$ Sriskandarajah's concluding statement expresses well the spirit of other book chapters: 'Given the global and interdependent scope of the challenges, it would seem wise to have global and interdependent approaches to tackling them' (181). Continuing this theme and having found that brain gain happens only when the Western African Union countries choose an industrialized country (such as France) as a target destination (222), Konseiga in fact suggests that building on global interdependence may be even more beneficial than building on regional interdependence.

Whenever global and interdependent approaches to tackling challenges of globalization are missing or ineffective, informal and clandestine structures fill this void. This is the message of Chin's article, that contends, 'Human migration including irregular migration is a natural human flow which cannot be forcibly stopped by governmental administrative means' (204). Based on his conversations with prospective illegal migrants from China, Chin shows that his interviewees question "why governments, either the Chinese government or any foreign government, do not provide them with a legal channel to go overseas and to reunite with their families' (198). Given the lack of legal channels, migrants build on the existing international human trafficking networks founded on the principles of 'kinship, local ties and dialect groups' (190) to go around the remaining barriers among countries. As suggested by Chin, irregular migration can be transformed into managed migration if the developed and developing countries find the will to honestly evaluate global labor demand and supply and to negotiate the movement of laborers. As a result, regulation of migration will dispel many illusions and thrills prompted by globalization, but it will also decrease the perils and pitfalls associated with global interdependence. 
In sum, to benefit from global interdependence, policymakers must actively manage the globalization process. But there is no 'silver bullet' for making this process instantly advantageous to all parties involved. Building on global interdependence requires constructive international dialogue, patience, experimentation and constant retooling of the available arsenal of adjustment. There is no easy way to satisfy all participants in global integration, but as suggested by the contributors to this book, it is possible to correct the existing biases and to articulate the commonly accepted international policies.

$* * *$

As implied by the articles in this book, the existence of the Butterfly Effect in reference to the world of human activity is no longer disputed: it is taken for granted. Indeed, an improvement in rice production technology in Cambodia can have implications for the world prices on rice, affecting not only poor Cambodians. And changing aid flows to Sub-Saharan Africa can influence both international trade and migration patterns, creating effects which can be felt well beyond the African continent.

In a separate study Peterson (2003) calls global interdependence a 'sobering reality'. Meanwhile, the costs and benefits of this 'reality' and the means of adjusting to and building on it in specific contexts remain contentious subjects. We hope this collection of articles will contribute to the better understanding of the dilemmas and struggles associated with global integration. We also hope that this volume will enhance the message of GDN's 2005 book Globalization and Equity: Perspectives from the Developing World. There is indeed a broad consensus that the developing world's entry into a global universe offers both 'roses and thorns'. Practical steps toward mutual accommodation - or at least consideration - between developing and developed countries, discussion of which runs through this book, can prevent huge crises and extend the 'freedom from want'. Any lessons from disparate experiences of various countries in addressing the challenges of globalization should therefore be helpful.

\section{NOTES}

1. The unfavorable balance between benefits and costs for developing countries as a result of the Uruguay Round was indicated by several authors (Croome 1998, Nogues 2005).

2. The Doha Development Agenda is interpreted as a step towards greater globalization of the world economy. For instance, as noted by Soloaga, the framework for agriculture seeks to reform global agricultural trade by the elimination of all forms of exports subsidies as well as 
all export measures with equivalent effect (e.g., exports credits, insurance programs) and by substantial reduction in tariffs.

3. Other researchers have proposed more specific practical steps to compensate developing countries for the loss of their human capital. They refer to tying development aid to human capital recruitment, sharing payroll and income tax revenues with poor-country providers of human capital, U.S.-style continuing post-emigration tax obligations to countries of origin, conditional education grants that are repayable on emigration, sharing the proceeds of visa fees or the revenues of visa auctions (Kapur and McHale 2005).

\section{BIBLIOGRAPHY}

Annan, Kofi (2001), Nobel Lecture, text available at http://nobelprize.org/nobel_prizes/ peace/laureates/2001/annan-lecture.html.

Bhagwati, Jagdish (2004), In Defense of Globalization, New York: Oxford University Press.

Bhagwati, Jagdish and T.N. Srinivasan (2002), 'Trade and Poverty in the Poor Countries', American Economic Review, 92 (2), 180-83.

Cho, George (1995), Trade, Aid and Global Interdependence, New York: Routledge.

Cline, William (2004), Trade Policy and Global Poverty, Washington, DC: Institute for International Economics, Center for Global Development.

Croome, John (1998), 'The Present Outlook for Trade Negotiations in the World Trade Organization', Washington, DC, World Bank, Policy Research Working Paper No. 1992.

Dinello, Natalia and Lyn Squire (eds) (2005), Globalization and Equity: Perspectives from the Developing World, Cheltenham, UK: Northampton, MA, USA, Edward Elgar.

Dollar, David and Aart Kraay (2001), 'Globalization, Inequality and Poverty Since 1980', World Bank: Washington, DC, available at http://worldbank research/ global.

(2002a), 'Growth is Good for the Poor', Journal of Economic Growth, 7 (3): $195-225$.

- (2002b), 'Trade, Growth and Poverty', Economic Journal, 114 (493), F22-F49.

Faini, Riccardo and Alessandra Venturini (1993), 'Trade, Aid and Migrations: Some Basic Policy Issues', European Economic Review, 37 (2 - 3), 435-42.

Faini, Riccardo, Jaime De Melo and Klaus F. Zimmermann (1999), Migration: The Controversies and the Evidence, New York: Cambridge University Press.

Hansen, Henrik and Finn Tarp (2000), 'Aid Effectiveness Disputed', Journal of International Development, 12 (3), 375-98.

Hatton, Timothy and Jeffrey Williamson (2003), 'What Fundamentals Drive World Migration?', Helsinki, World Institute for Development Economics Research, Discussion Paper No. 2003/23.

Hertel, Thomas and L. Alan Winters (2005), 'Estimating the Poverty Impacts of a Prospective Doha Development Agenda', a paper available at http://www.gdnet.org/ impact/Resource_Centre/Hertel_Winters_WorldEconomy.pdf.

Kapur, Devesh and John McHale (October 2005), 'The Global Migration of Talent: What Does it Mean for Developing Countries?', CGD Brief, available at www. cgdev.org/content/publications/detail/4473.

Killick, Tony (2002), 'Inequality Briefing', London, UK Department for International Development, Briefing Paper No. 3. 
Lancaster, Carol and Samuel Wangwe (2000), Managing a Smooth Transition from Aid Dependence in Africa, Washington, DC: Overseas Development Council.

Lucas, Robert (2005), International Migration Regimes and Economic Development, Lyme, CT: Edward Elgar.

McCulloch, Neil, Alan L. Winters and Xavier Cirera (2001), Trade Liberalization and Poverty: A Handbook, London: Centre for Economic Policy Research.

Nogues, Julio J. (2005), 'Unequal Exchange: Developing Countries in the International Trade Negotiations', Economics Working Paper Archive, International Trade Series, No. 0502011.

Peterson, Peter (2003), 'Global Interdependence: A Sobering Reality,' Annual Essay, The Conference Board 2003 Annual Report, available at http://www.conferenceboard.org/pdf_free/annualessay2003.pdf.

Radelet, Steven (April 2004), 'Aid Effectiveness and the Millennium Development Goals', Washington, DC, Center for Global Development, Working Paper No. 39.

Sachs, Jeffrey, John McArthur, Guido Schmidt-Traub, Margaret Kruk, Chandrika Bahadur, Michael Faye and Gordon McCord (2004), 'Ending Africa's Poverty Trap,' Brookings Papers on Economic Activity, No. 1, 117-240.

Sobhan, Rehman (1982), The Crisis of External Dependence: The Political Economy of Foreign Aid to Bangladesh, Dhaka, Bangladesh: University Press.

Srinivasan, T.N. and Jagdish Bhagwati (1999), 'Outward Orientation and Development: Are Revisionists Right?' festschrift for Anne Krueger, Columbia University, New York, 19 September 1999, available at http://www.Columbia.edu/ jb38/ Krueger.pdf.

Stiglitz, Joseph E. and Andrew Charlton (2004), The Development Round of Trade Negotiations in the Aftermath of Cancun, Report of the Commonwealth Secretariat and the Initiative for Policy Dialogue.

Streeten, Paul (2001), 'Integration, Interdependence and Globalization', Finance and Development, 38 (2).

Svensson, Jakob (2000), 'Foreign Aid and Rent-Seeking', Journal of International Economics, 51 (2), 437-61.

Tarp, Finn and Peter Hjertholm (eds) (2000), Foreign Aid and Development: Lessons Learned and Directions for the Future, London: Routledge.

van de Walle, Nicolas (2005), Overcoming Stagnation in Aid-Dependent Countries, Washington, DC: Center for Global Development.

Venables, Anthony J. (1999), 'Regional Integration Agreements: A Force for Convergence or Divergence?', Washington, DC, World Bank, Country Economics Department Working Paper No. 2260.

Winters, L. Alan, Neil McCulloch and Andrew McKay (2004), 'Trade Liberalization and Poverty: The Evidence So Far', Journal of Economic Literature, 42 (1), $72-115$.

World Bank (2002), Globalization, Growth, and Poverty: Building an Inclusive World Economy, New York: Oxford University Press. 